\title{
Flood Hazard Mapping Using Two Digital Elevation Models: Application in a Semi-Arid Environment of Morocco
}

\author{
Bennani Oumaima, \\ Laboratory of Geosciences and Environment, \\ Cadi Ayyad University, Marrakesh, Morocco \& UMR GRED \\ (Univ. P. Valery, IRD), Montpellier, France \\ Tramblay Yves, \\ HSM (IRD, CNRS, Univ. Montpellier), Montpellier, France \\ Saidi Mohamed El Mehdi, \\ Cadi Ayyad University, Marrakesh, Morocco

\section{Gascoin Simon,} \\ CESBIO (CNRS, IRD, CNES, Univ. P. Sabatier), Toulouse, France \\ Leone Frederic, \\ UMR GRED (Univ. P. Valery, IRD), Montpellier, France
}

Doi:10.19044/esj.2019.v15n33p338 URL:http://dx.doi.org/10.19044/esj.2019.v15n33p338

\begin{abstract}
The High Atlas of Morocco is a semi-arid mountainous environment that frequently suffers from natural hazards. For example, the watersheds upstream of Marrakech city are subject to extreme floods, caused by heavy rains. These episodes are frequent and often devastating, as was the August 1995 event that caused hundreds of deaths in the Ourika Valley. The purpose of this work is to characterize the risk of flooding in this valley, by simulating the water levels and the floodplain extension. This watershed of the Ourika is characterized by a high relief, a rugged topography and a low permeability substratum. To perform this hydraulic simulation, the resolution and accuracy of Digital Elevation Models (DEM) can strongly impact the results in terms of water levels and flow velocities during floods. Two digital elevation models (DEM) were compared: a DEM ASTER with a spatial resolution of $30 \mathrm{~m}$ and a DEM derived from stereoscopic images of Pleiades with a resolution of $4 \mathrm{~m}$. Using a hydraulic model (HEC-RAS) and the two DEM resolutions, flood areas corresponding to different return periods are simulated and compared. For the assessment of the two DEM, many areas are selected that are characterized by different types of exposure: highly frequented tourist areas near a regional road and agricultural areas on alluvial terraces, where
\end{abstract}


cultivated fields and infrastructure are vulnerable. The results showed that the high-resolution Pleiades DEM allows for accurate mapping of floodplains in complex terrain, as it realistically represents the topography and allows correct simulation of observed water levels. This study highlights the added value of a high-resolution remote sensing for flood modeling in areas where data are scarce.

Keywords: Hydraulic modeling, Floods, HEC-RAS, Ourika, DEM, Pleiades

\section{Introduction}

Flooding is a major risk in particular for developing countries (Douglas et al., 2008). Despite the fact that there are several ongoing initiatives to reduce the consequences of floods on people and infrastructures, the socio-economic damage they cause continues to increase particularly in many countries, such as Morocco (Di Baldassarre et al., 2010a). Several studies have shown that the damages are not solely related to the frequency or magnitude of the hydrological hazards, but also to the increasing urbanization of areas likely to be flooded (Taous et al., 2010, Vinet et al., 2016). In Morocco, there is a growing awareness about floods since some decades. This is partly because of the extension of urban and suburban areas in flood-prone areas. These floods are sometimes very damaging for both residential infrastructures and agriculture, they have caused many casualties among the population like the catastrophic event of the Ourika valley in 1995 (Saidi et al., 2003). Consequently, after 1995 several mitigation measures involving the construction of structures reducing the impacts of floods and a warning system have been implemented (Saidi et al. 2010).

Flood mapping and the identification of areas at risk of flooding are the main steps in the formulation of any flood management strategy (Di Baldassarre et al., 2010b, Patel et al., 2017). In order to reduce the casualties and the damages to infrastructures in floodplains, it is necessary to predict river water levels including the flood extent for risk mapping (Timbadiya et al., 2014, Patel et al., 2017). Several approaches have been developed to model flood risk (Di Baldassarre et al., 2010b, Teng et al., 2017). The assessment of flood risk for planning-relevant scenarios is usually performed using hydrological and hydraulic models. However, in many regions such as in Morocco, the scarcity of data is the main difficulty to implement these approaches (Werren et al., 2015). The lack of precipitation and discharge data limit the use of hydrological modeling for these semi-arid areas of North Africa (Gaume et al. 2009). Furthermore, the hydrological response of semiarid mountainous catchments of South of Morocco is characterized with fast response time of runoff to a rainfall event, often with a high intensity of rainfall 
(Latron et al., 2009) causing flash- flood events that are difficult to monitor with hydrometric gauges (Borga et al., 2010, Mehreb et al., 2016).

Hydraulic models such as HEC-RAS, LISFLOOD-FPS or IFAS are widely used for flood risk mapping (Horritt and Bates, 2002, Knebl et al., 2005, Apel et al., 2006, Dutta et al., 2006, Di Baldassarre et al., 2010b, Teng et al., 2017, ), flood damage assessment (Merz et al., 2010) and flood forecasting in real time (Arduino et al., 2005, Teng et al., 2017). These numerical models are important tools for understanding and evaluating flood events given the strong non-linear dynamics of floodplain flows. A common approach is to apply these numerical models at various spatial scales with different DEM sources to compare the model errors (Jung et al., 2015, Dawod and Al-Ghami, 2017). Indeed, flood risk mapping requires precise data on the topography (Noman et al., 2001, Tate et al., 2002, Papaioannou et al., 2016) and a realistic digital elevation model (DEM) is a critical input of hydraulic models (Pereira-Cardenal et al., 2011, Musa et al., 2015). The accuracy of hydraulic calculations depends on the quality of DEM used and small changes in the water level can induce major changes in the flooded area. The spatial resolution of the DEM is the most crucial parameter (Papaioannou et al., 2016), surface features, typically crevices or debris cover, must be identified from the available resolution Kääb, (2002).

In Morocco some flood studies have been conducted so far, while the vulnerability of the country to floods is high (Mehreb et al., 2016). Saidi et al., (2003) have demonstrated the role of the physical environment in the amplification of floods in mountain environment using the example of the flood of August 17, 1995 in the Ourika Valley (Haut-Atlas, Morocco). Zkhiri et al. (2016) provided a regional flood frequency analysis in High-Atlas mountainous basins, including the Ourika. Tramblay et al. (2012) developed a model for floods upstream of the Makhazine dam in northern Morocco. Zemzami et al. (2012) adapted the Gradex method in North Morocco to estimate extreme discharge level. Zoglat et al., (2014) proposed a peak over threshold modeling of peaks floods in the Loukkos basin in northern Morocco. Fewer studies have tried to model flood vulnerability in Morocco. In this context, Werren et al., (2015) proposed a mapping of flood areas in the Middle Atlas by taking advantage of hydro-geomorphological mapping and post-flood estimates instead of measured hydrometric data. Theilen-Willige et al. (2015) used Landsat 8 Images for flood damage mapping in southern Morocco. Karrouchi et al. (2016) worked on the mapping of flood risk areas in the Tangier-Tetouan region of North Morocco with a hydraulic approach. Mallouk et al. (2015) used a multi-criteria mapping approach to assess vulnerability to flood risk in urban areas of Casablanca, Morocco. El Fels et al. (2014) using a 30 meter resolution DEM carried out a simulation and mapping of flood risk in the Ourika valley. 
The goal of this work consists in characterizing the flood hazard by simulating the water levels and the lateral floodplain extension during floods using two DEM with different resolutions. This study focuses on the analysis of floods hazard of the Ourika basin, as a case study in Morocco where the deadliest flood event of the country was recorded in 1995. First, we introduce the study area and the data used. In a second section, the methods for predetermination of extreme flows return levels and the hydraulic modeling are described. The third section is dedicated to results and discussion. Finally, conclusion is drawn in the last section.

\section{Study area and data:}

\subsection{Study area:}

The catchment area of Ourika $(503 \mathrm{~km})$ is part of the Tensift watershed in the Marrakech region, South of Morocco (Fig. 1). About 40km to the Southeast of the city of Marrakech, it is located between latitude 31 and $31^{\circ}$ 20 'North and between longitude $7^{\circ} 30^{\prime}$ and $7^{\circ} 60$ 'West. It is bordered on the east by the watershed of Zat, and on the west by the Rheraya basin. At the outlet of Aghbalou, it is limited to the north by the plain of Haouz, to the south by the Hig-Atlas mountainous range. The Ourika basin is characterized by high elevation and rugged topography. $75 \%$ of the basin is located between 3200 and $1600 \mathrm{~m}$ a.s.1.. The average altitude is $2500 \mathrm{~m}$. The slopes range from 0 to $20^{\circ}$ in the main water court. Slopes are steep in the upstream part of the basin, where they can reach 60 to $70^{\circ}$. These slopes accelerate runoff and favor the development of high floods in case of intense rains. The substratum is not very permeable and the hydrographic network is dense, thus favoring runoff. 

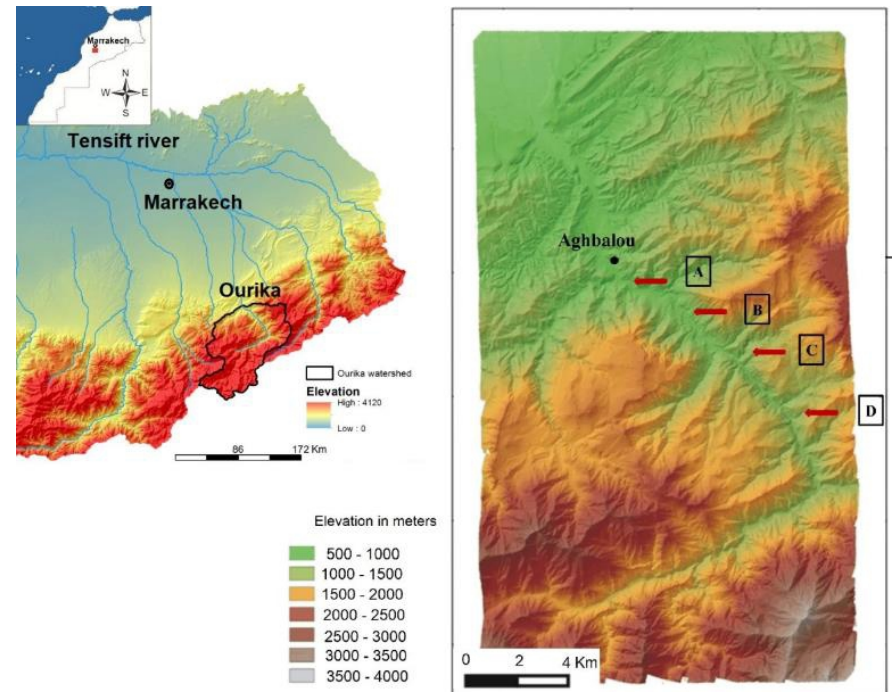

Figure 1: Geographical location of the Ourika catchment in Morocco and presentation of the four cross sections of the river considered (noted A, B, C, D)

The hydrological context of the Ourika watershed is influenced by a very marked seasonal and inter-annual irregularity of precipitation and heterogeneity of their spatial distribution. (Saidi et al., 2003, Zkhiri et al., 2016). This hydraulic system is causing serious flooding by the extension of water bodies during periods of heavy rainfall, which affects the populations and the infrastructures. Moreover, with growing urbanization and climate change, the susceptibility of the Ourika watershed to being affected by floods is potentially becoming increasingly important. The floods threaten the economic development, infrastructure and natural ecosystems of the region. In the Ourika basin, the major floods may cut the road that connects the valley with Marrakesh city, especially as the valley is linked to the plain downstream by only a single vulnerable road (Daoudi and Saidi, 2008). On August 17, 1995, the Marrakesh High-Atlas, particularly the Ourika Valley, experienced a flood that occurred in an unexpectedly brutal way. In an unprecedented short time (10 min), the flood caused loss of life, with more than 200 people dead and many missing and enormous material damage (Daoudi and Saidi, 2008). The extreme weather events that occurred in the last few years have demonstrated the necessity of trustworthy flood models, as emergency managers and city planners realize the importance of warning systems to mitigate the impacts of severe storms. Particularly since the touristic frequentation is high throughout the year, especially during the summer, and many touristic infrastructures such as hotels and restaurants are located nearby the river bed. As shown on Figure 1, four different cross section of the river 
have been considered (a,b,c and d), characterized by different types of exposure to flood risk: touristic areas highly frequented near to a regional road (sections c and d) and agricultural areas on alluvial terraces (sections a and b), where cultivated fields and infrastructures are vulnerable.

\subsection{Data collection:}

\subsubsection{Extraction of the maximum daily flows:}

The database consists of annual maximum flows measured at the hydrometric station of Aghbalou. These data cover a period of 45 years, from 1969 to 2014. They are derived from manual gauges and automatic measurements of water levels, and are provided by the Marrakech Hydraulic Basin Agency (ABHT).

\subsubsection{Digital elevation models}

The launch of Pleiades satellites in late 2011 and 2012 helped to develop new optical image acquisition capabilities at very high resolution, in the particular field of crisis management, but also more widely in different themes of Earth Observation (Yésou et al., 2015). The Pleiades system consists of a constellation of two identical satellites for VHR panchromatic (PA) and multispectral (XS) optical observation of the Earth's surface. Both satellites fly in sun-synchronous orbits with $98.2^{\circ}$ inclination and an offset of $180^{\circ}$ from each other, which allows a minimum revisit time of $24 \mathrm{~h}$. The Pleiades system is the first of its kind capable of acquiring three or more nearly synchronous images of the same area with a stereo angle varying between $6^{\circ}$ and $28^{\circ}$ (Bagnardi et al., 2016). This stereoscopic capability enables to make accurate, high resolution digital elevation model (DEM) of the land surface in complex terrain (Lacroix et al., 2015). A Pleiades 1B stereo-pair was acquired over the Ourika catchment on 07 July 2016. We used the Ames Stereo Pipeline (Shean et al.,2016) to generate a DEM with a pixel resolution of $4 \mathrm{~m}$ in the UTM cartographic system following the procedure outlined in (Marti et al., 2016). The circular error of absolute horizontal geolocalization (CE90) of Pleiades images is lower than $6.5 \mathrm{~m}$ (Gleyzes et al., 2012). This absolute horizontal error can be substantially reduced by using only one ground control point (Lacroix et al., 2015). Previous studies using Pleiades stereoscopic images in sparsely vegetated mountainous areas indicate that the relative accuracy in the vertical direction reach $0.6 \mathrm{~m}$ (Lacroix et al., 2015). On the other hand, the accuracy of the ASTER GDEM is known to be at least an order of magnitude higher in the same terrain configuration (Lacroix et al., 2015).

ASTER is an advanced multispectral imager that was launched aboard NASA's Terra spacecraft in December 1999. It has three visible near-infrared (VNIR) spectral bands, six short-wave infrared bands ( SWIR), and five bands in thermal infrared regions (TIR), with a ground resolution of 15, 30 and 90 
m, respectively (Yamaguchi et al., 1998; Forkuor and Maathuis, 2012). The Ministry of Economy, Trade and Industry of Japan (METI) and NASA of the United States jointly published a global DEM (ASTER: Advanced Radiometric Emission and Heat Reflection Radiometer, GDEM: Global Digital Elevation Model) derived from ASTER imagery acquired since its launch (1999) until the end of August 2008. It covers land areas between 830 $\mathrm{N}$ and $830 \mathrm{~S}$, including 22,600 10-by-10 tiles. The GDEM is supplied at a resolution of one second of arc $(30 \mathrm{~m})$ and referenced to the World Geodetic System (WGS) 1984. The elevations are calculated relative to the geoid WGS 84 EGM96 (Fujisada et al., 2005, Frukuor and Maathuis, 2012).

\section{Methods:}

The methodology is based on:

(1) The predetermination of extreme flood return levels, according to a probability distribution fitted to observed data (Stedinger et al., 1993)

(2) The simulation of the extent of floods associated with predetermined flow levels using the HEC-RAS (Hydrologic Engineering Center - River Analysis System) computer tool (Brunner, 2016).

\subsection{Frequency analysis:}

Frequency analysis is one of the main tools for estimating river discharge for a given return period. It is used when there is sufficient at site hydrological data and is based on a statistical methods in order to define the probability of occurrence of floods (Stedinger et al., 1993; Ahattab et al., 2015). The annual maximum discharge values were extracted from the observed time series. Prior to the fitting of different statistical distributions, the time series must comply with the hypothesis of stationarity, homogeneity and independence. To verify these hypotheses, three nonparametric tests were used since the distribution of the data is unknown, but assumed non-normal, as it is most frequently the case for extreme values (Tramblay et al., 2008):

- The Wald-Wolfowitz (1943) test the hypothesis of independence (i.e., the absence of autocorrelation)

- The Mann-Kendall test (1945) evaluates the presence of a trend in the data.

- The Wilcoxon (1945) tests for homogeneity, by comparing the median of two samples.

The maximum likelihood method is used to estimate the parameters of all adjusted distributions (El Adlouni et al., 2008). It makes it possible to estimate from an observed sample, the best parameters of a probability law, so that the likelihood obtained is maximized (El Alaoui El Fels et al., 2014). There are different statistical distributions adapted to maximum annual flood series (Stedinger et al., 1993; Rao and Hamed, 2001, El Adlouni et al., 2008). 
For our flood sample, several theoretical distributions commonly used to represent floods in this region were tested including the Gamma, Generalized Extreme Value, Gumbel and Log-Normal distributions (fig. 2).

The best distribution for the data series is based on the Akaike (1974) and Bayesian (Schwartz 1978) information criteria. Both are based on the likelihood function, and respectively illustrated in equation (1) and (2):
$\mathrm{AIC}=-2 \log (L)+2 k$
$\mathrm{BIC}=-2 \log (L)+2 k \log (N)$

Equations (1) and (2) result the AIC (Akaike information criterion) and the BIC (Bayesian information criterion) with $\mathrm{L}$ the likelihood function, $\mathrm{k}$ the number of parameters, $\mathrm{N}$ the sample size. The best distribution is associated with the smallest BIC and AIC values (Rao and Hamed, 2001, Tramblay et al., 2008).
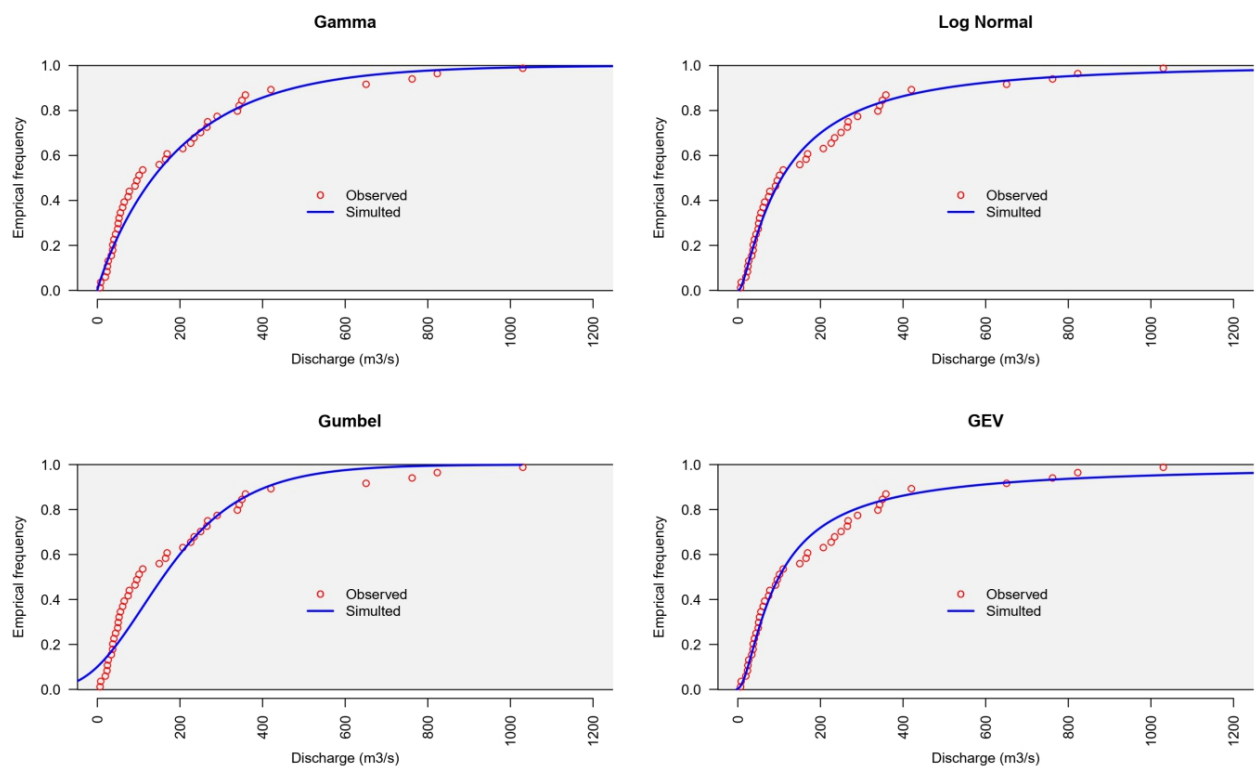

Figure 2: Adjustment of analytical distribution functions to peak discharges of Ourika floods

\subsection{Hydraulic Modelling:}

The hydraulic simulation aims to represent the extension of the flood wave in the river, to delineate the floodplains and to simulate water levels. The computational algorithms is used by the numerical models that consist of onedimensional or two-dimensional water surface models (Horritt and Bates, 2002, Nardi et al., 2006; Sarhadi et al., 2012) in order to solve the governing river flow and floodplains equation. The tool used to perform the hydraulic simulation is the HEC-RAS (4.1.0) model developed by U.S. Army Corps of Engineers in the Hydrologic Engineering Center (Brunner, 2016). HEC RAS 
rely a river geometry to a digital terrain model to result a water depth and a water velocity surface (Pistocchi and Mazzoli, 2002) for the interpolated section. The version used is based on the solution of the one-dimensional energy equation, with no direct modelling of the hydraulic effects of cross section changes or higher dimensional aspects of flow. It is probably one the most used hydraulic model (Teng et al., 2017) and has been successfully applied in catchments of Morocco (El Fels et al., 2014).

The Manning roughness coefficient is the main parameter of the hydraulic model since it defines the reaction of the river flow according to the terrain, influencing the velocity. In the absence of sufficient data to calibrate this coefficient (such as flooded areas or water levels from extensive field surveys), the mapping of the land use is necessary to estimate the values for this coefficient of roughness. We used both land-use data digitized from a 2009 GeoEye image provided by Google Maps, and vegetation cover data obtained from the ESA GlobCover 2009 (Arino et al, 2008) to obtain a land use map for the catchment. Similarly as in Werren et al. (2015), for each type of land use a coefficient of roughness has been estimated according to the table given in Chow (1959).

\section{Results and discussion}

\subsection{Instantaneous peak flow distribution}

In the frequency analysis, we used the annual maximum approach. According to the results of Mann-Kendall, Wilcoxon and Wald-Wolfowitz tests illustrated in Table 1, we concluded that the time series used complies with the assumptions of stationarity, homogeneity and independence. In the results of the fitting of different statistical distribution, we note that among the different distributions used, the adjustment of the Log-Normal distribution to the annual maximum discharges at the station of Aghbalou has shown satisfactory adequacy graphically as well as statistically. As it shown in Table 2, the smallest BIC and AIC values are obtained with this distribution and consequently the flood quantiles for different return levels have computed with the Log-Normal distribution (Table 3).

Table 1: pvalues of the tests of stationarity, homogeneity and independence

\begin{tabular}{l|c}
\hline Test of stationarity ( Mann-Kendall) & 0.1405 \\
\hline Test of homogeneity (Wilcoxon) & 0.27 \\
\hline Test of independence (Wald-Wolfowitz) & 0.64 \\
\hline
\end{tabular}


Table 2: AIC and BIC Criterions for the different distributions

\begin{tabular}{lll}
\hline Distribution & BIC & AIC \\
\hline Log Normal & $\mathbf{5 6 8 . 1 7}$ & $\mathbf{5 6 4 . 5 6}$ \\
\hline Gamma & 573.72 & 570.10 \\
\hline GEV & 573.76 & 568.34 \\
\hline Gumbel & 596.42 & 592.807 \\
\hline
\end{tabular}

Table 3: Estimates of peak flows for different return periods in the Ourika

\begin{tabular}{llllll}
\hline $\begin{array}{l}\text { Return } \\
\text { period }\end{array}$ & 5-year & 10-year & 20-year & 50-year & 100-year \\
\hline $\mathbf{Q}\left(\mathbf{m}^{\mathbf{3}} \mathbf{s}^{-\mathbf{1}}\right)$ & 284 & 465 & 697 & 1100 & 1490 \\
\hline
\end{tabular}

\subsection{Comparison of Pleiades and ASTER DEM rivers sections}

Hydraulic modeling involves calculating water levels to produce flood risk maps that indicate the maximum extent of the flooded area corresponding to a simulated flow. The results presented here allow us to compare the Pleiades DEM to the ASTER DEM based on the resolution. The cross-sections with Pleiades DEM and the ASTER DEM are displayed on Figure 3, with water heights computed for different return periods in each cross-section considered. Comparing the diverse cross-sections obtained with both DEM resolutions show important differences. The DEM derived from Pleiades allow a very precise topography that is realistic by comparison with ground observations. We can therefore conclude that the different cross-sections and in particular the (a) and (d) sections are not correctly reproduced in the ASTER product and not realistic, because of the strong smoothing caused by the low resolution. 


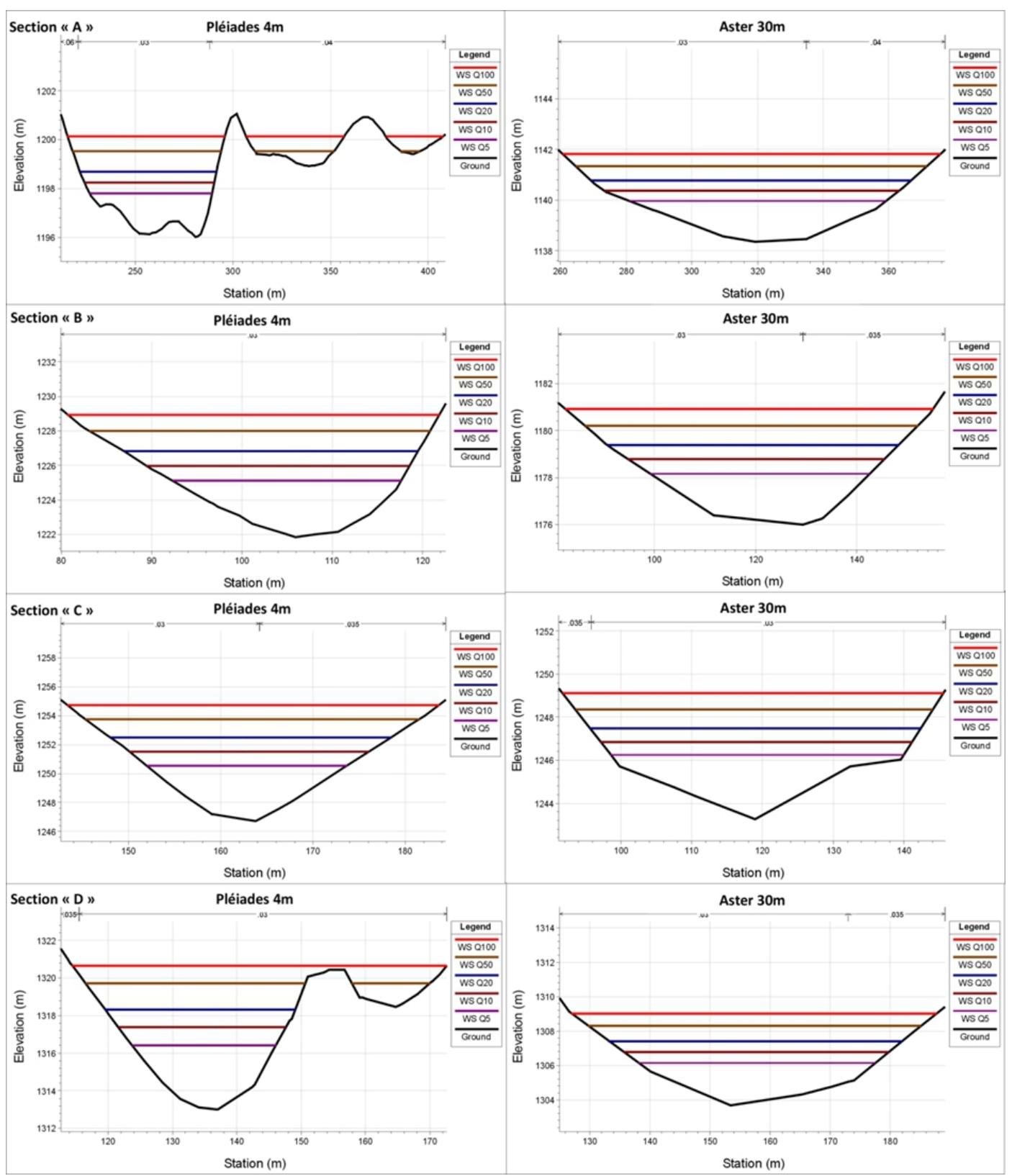

Figure 3: 2D mapping of the different cross sections and water levels computed for different return levels

\subsection{Hydraulic modeling results}

For the different return periods, the tables 4 and 5 give an overall view of the flow characteristics computed for each section studied, in terms of flooded area and maximum water level as basic elements for flood hazard assessment. These parameters give us several indications about the flow dynamics in the area studied, such as the slopes at each section, depending on 
the DEM resolution. When comparing the results between the two resolutions of DEM used, a remarkable difference can be seen and especially for water levels. The water levels calculated from the Pleiades DEM are more important than those obtained with the ASTER DEM, which underestimates the water levels between $-46 \%$ and $-25 \%$ depending on the river section $(-26 \%$ on average). On the opposite, the flooded areas obtained with the ASTER DEM are on average $15 \%$ larger than flooded areas obtained with the Pleiades DEM, due to lower resolution that does not allow a correct reproduction of the steep slopes on each side of the river bed (in particular for sections (a) and (d)). This indicates that the ASTER DEM provides unrealistic estimates of flood maps, due to its coarse resolution that does not allow representing the channel.

There is a need to validate the flood extent and water levels simulated by the HEC-RAS model with field measurements. However, such field surveys have not been organized in the Ourika basin systematically after flood events. Only for the 1995 flood some post-flood analyses have been conducted by the Tensift basin hydraulic agency. Estimates of the water levels reached during the 1995 flood are based on the testimonies of local people; they can be associated with strong uncertainties. As a rare example of an observed water level reported on a building, the Figure 4 show the section " $\mathrm{C}$ " located in the area of Oulmes which experienced during the flood of 1995 impressive damages. The height of water was estimated to be around $7 \mathrm{~m}$, according to the testimonies of residents and high-water marks and flood damages on buildings (Fig.4, 5). This validates the results obtained using hydraulic modeling with Pleiades DEM as shown in Table 4, indicating that the estimated water height for flood with a 50-year return level, corresponding to the 1995 flood, is $6.9 \mathrm{~m}$. While for the modeling done with ASTER DEM, the Table 5 shows that for the same return period, the water level is slightly underestimated with a value of $5.09 \mathrm{~m}$. This indicates that the water levels obtained with the Pleiades DEM are closer to those observed than water levels obtained with Aster DEM. However, this result must be confirmed by more field surveys and the reporting the actual extension of floods. 
Table 4: Table summarizing the flood characteristics for different sections with Pleiades Section "A" Section "B" Section "C"

Section "D"

\begin{tabular}{llllllllll}
\hline $\begin{array}{l}\text { Return } \\
\text { period }\end{array}$ & $\begin{array}{l}\mathbf{Q} \\
\text { max. } \\
\left(\mathbf{m}^{\mathbf{3}} \mathbf{s}^{-\mathbf{1}}\right)\end{array}$ & $\begin{array}{l}\text { Flow } \\
\text { area } \\
\left(\mathbf{m}^{\mathbf{2}}\right)\end{array}$ & $\begin{array}{l}\text { Height } \\
\text { of water } \\
(\mathbf{m})\end{array}$ & $\begin{array}{l}\text { Flow } \\
\text { area } \\
\left(\mathbf{m}^{\mathbf{2}}\right)\end{array}$ & $\begin{array}{l}\text { Height } \\
\text { of water } \\
(\mathbf{m})\end{array}$ & $\begin{array}{l}\text { Flow } \\
\mathbf{a r e a} \\
\left(\mathbf{m}^{2}\right)\end{array}$ & $\begin{array}{l}\text { Height of } \\
\text { water } \\
(\mathbf{m})\end{array}$ & $\begin{array}{l}\text { Flow } \\
\text { area } \\
\left(\mathbf{m}^{\mathbf{2}}\right)\end{array}$ & $\begin{array}{l}\text { Height } \\
\text { of } \\
\text { water } \\
(\mathbf{m})\end{array}$ \\
\hline $\mathbf{5}$ years & 284 & 54.84 & 2.99 & 52.06 & 3.27 & 49.2 & 3.7 & 49.77 & 3.43 \\
\hline $\mathbf{1 0}$ years & 465 & 83.09 & 3.81 & 75.85 & 4.14 & 72.59 & 4.68 & 72.94 & 4.39 \\
\hline 20 years & 697 & 112.37 & 4.52 & 102.19 & 4.99 & 100.01 & 5.66 & 98.44 & 5.3 \\
\hline 50 years & 1100 & 158.38 & 5.49 & 143.38 & 6.16 & 142.01 & 6.92 & 152.61 & 6.7 \\
\hline $\mathbf{1 0 0}$ years & 1490 & 199.92 & 6.27 & 180.72 & 7.11 & 179.98 & 7.91 & 202.36 & 7.66 \\
\hline
\end{tabular}

Table 5: Table summarizing flood characteristics for different sections with Aster

\begin{tabular}{cccccccccc}
\hline & \multicolumn{3}{c}{ Section "A" } & \multicolumn{2}{c}{ Section "B" } & \multicolumn{2}{c}{ Section "C" } & \multicolumn{2}{c}{ Section "D" } \\
\hline $\begin{array}{c}\text { Return } \\
\text { period }\end{array}$ & $\begin{array}{c}\mathbf{Q} \\
\mathbf{m a x} . \\
\left(\mathbf{m}^{\mathbf{3}} \mathbf{s}^{-}\right.\end{array}$ & $\begin{array}{c}\text { Flow } \\
\text { area } \\
\left(\mathbf{m}^{\mathbf{2}}\right)\end{array}$ & $\begin{array}{c}\text { Height } \\
\text { of water } \\
(\mathbf{m})\end{array}$ & $\begin{array}{c}\text { Flow } \\
\text { area } \\
\left(\mathbf{m}^{2}\right)\end{array}$ & $\begin{array}{c}\text { Height } \\
\text { of water } \\
(\mathbf{m})\end{array}$ & $\begin{array}{c}\text { Flow } \\
\text { area } \\
\left(\mathbf{m}^{\mathbf{2}}\right)\end{array}$ & $\begin{array}{c}\text { Height of } \\
\text { water } \\
(\mathbf{m})\end{array}$ & $\begin{array}{c}\text { Flow } \\
\text { area } \\
\left(\mathbf{m}^{2}\right)\end{array}$ & $\begin{array}{c}\text { Height } \\
\text { of water } \\
(\mathbf{m})\end{array}$ \\
\hline 5 years & 284 & 78.33 & 1.6 & 62.95 & 2.18 & 60.93 & 3 & 59.98 & 2.47 \\
\hline $\mathbf{1 0}$ years & 465 & 112.24 & 2 & 92.17 & 2.8 & 86.19 & 3.59 & 86.46 & 3.1 \\
\hline 20 years & 697 & 150.19 & 2.41 & 124.17 & 3.4 & 115.08 & 4.23 & 116.25 & 3.75 \\
\hline $\mathbf{5 0}$ years & 1100 & 208.48 & 2.98 & 175.56 & 4.23 & 156.99 & 5.09 & 162.7 & 4.64 \\
\hline 100 years & 1490 & 262.7 & 3.47 & 224.03 & 4.92 & 197.51 & 5.87 & 204.27 & 5.35 \\
\hline
\end{tabular}




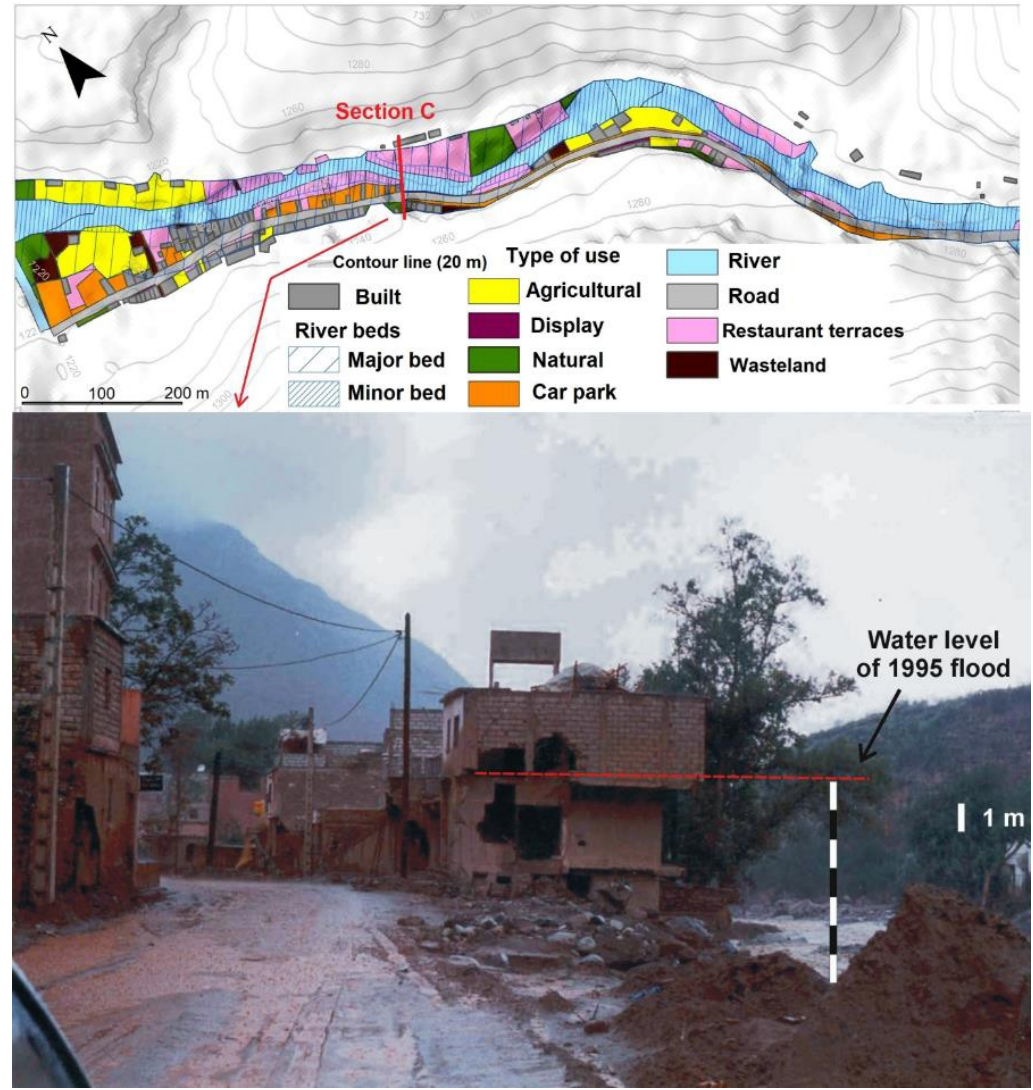

Figure 4: Section "C" on the Ourika river, in the Oulmes village. The upper panel present the different types of land use and the lower panel is the water level observed during the 1995 flood (Picture by Tensift Hydraulic Basin Agency -ABHT)

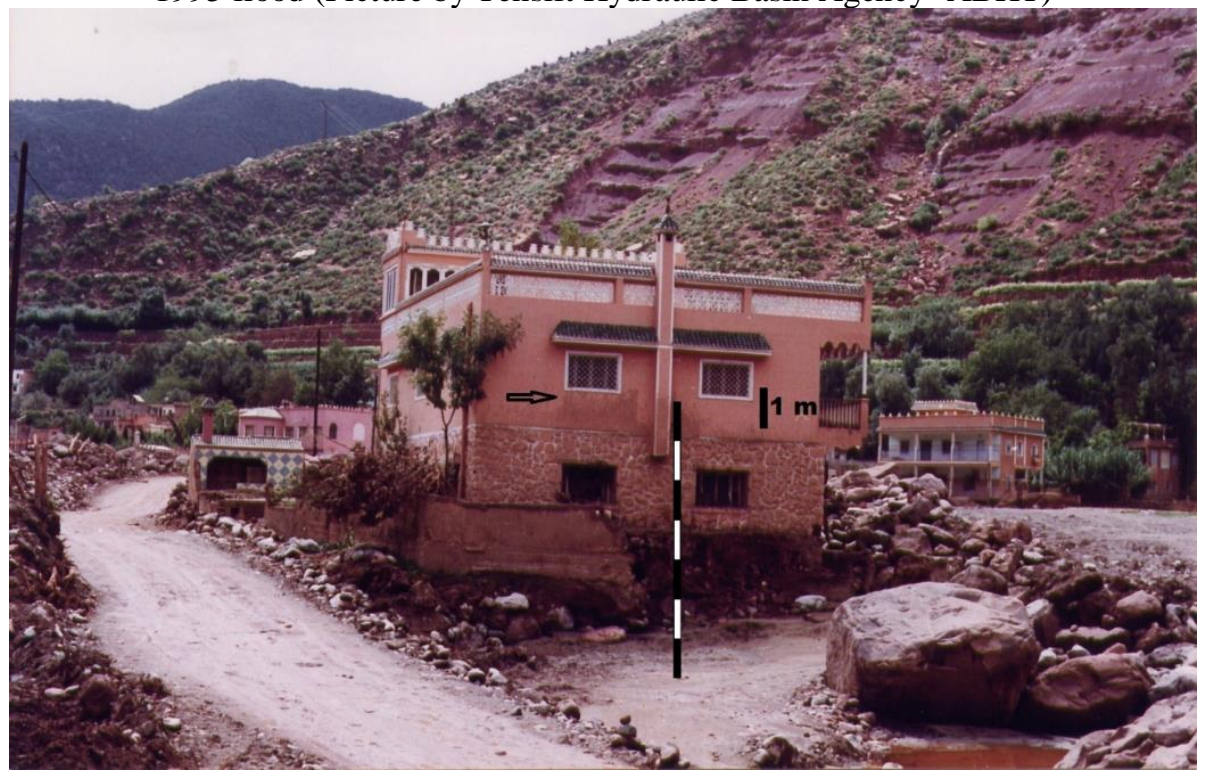

Figure 5: Other example of the water level reached during the 1995 flood 


\subsection{Mapping of flooded areas}

From the results in one dimension in HEC-RAS, we can also visualize the results of the flood propagation for different periods of return on a 2D map. For this, the results of the hydraulic simulation are operated by a GIS tools to create maps of the flood plain for a flood corresponding to a return period of 100 years (Figure 6). The simulation of the lateral extension of these floods highlights significant overflows of the watercourse on its banks. According to the flood magnitudes obtained for different return periods, floods can inundate agricultural fields, buildings, and may also cut the provincial road P-2017, which is the only road connecting the valley to the city of Marrakesh. The use of the Pleiades data makes it possible to describe the severity of an event in term of spatial extension, because it allows a very detailed mapping of the flood zones. We observe that certain portions of the river are more prone to flooding due to the difference in altitude. The extent of the flood and the water depths are much higher downstream than upstream of the river profile. With the Pleiades DEM, the effect of the downstream migration of the flood is seen: the flood extension in the upstream portion remains close to the main river bed, while the downstream portion is in turn strongly affected with flooded areas largely extended, due to the contribution of upstream water. This feature is not present when using the ASTER DEM, to the unrealistic representation of the river cross-sections. 


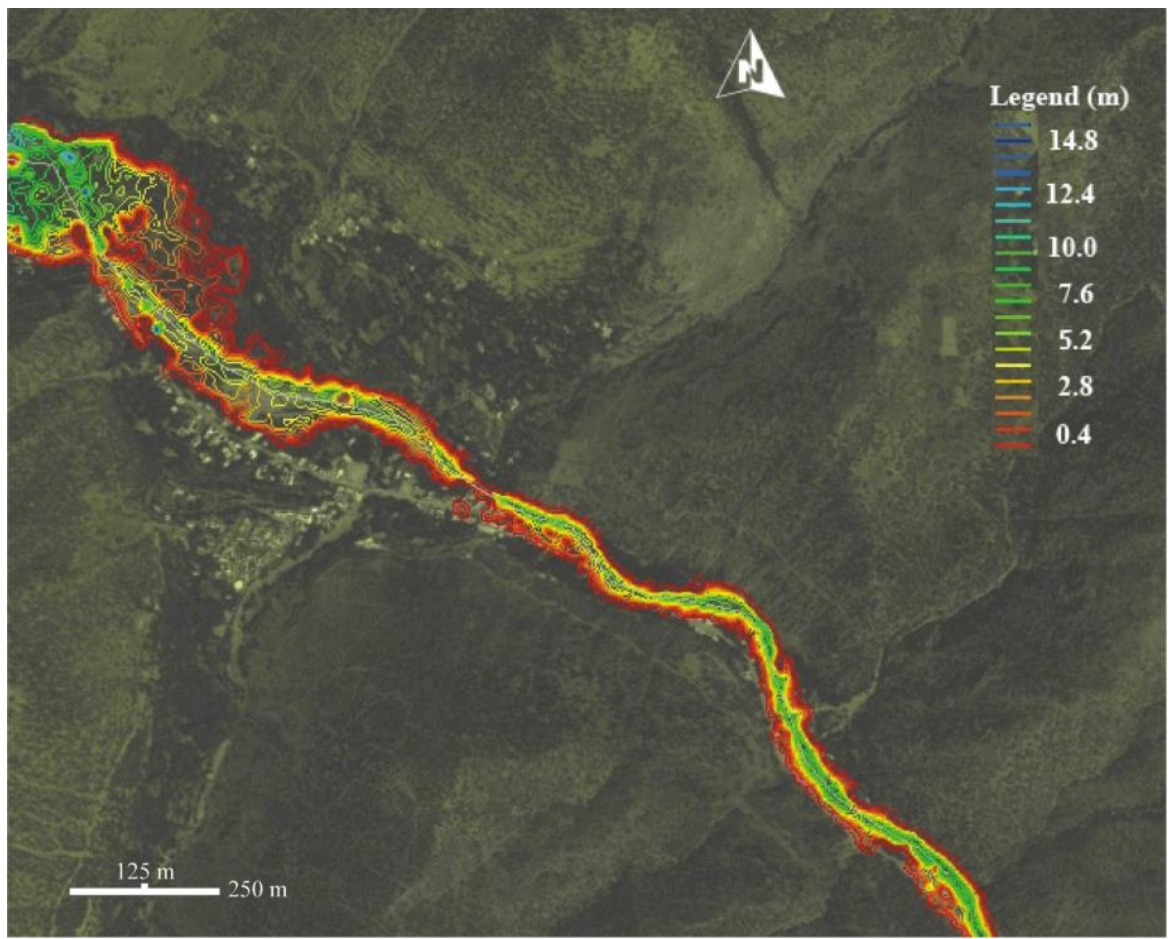

Figure 6: Mapping of floodplain extension simulated with the Pleiades DEM

\section{Conclusions and perspectives:}

The goal of this work was to compare two different DEM products to produce flood risk maps in the High-Atlas catchment of Ourika in South Morocco. The results of the hydraulic modeling show that the low-resolution DEM (ASTER 30m) underestimate the flood risk. There are significant differences in the water levels between the ASTER DEM and the Pleiades DEM due to the fact that the latter allows a higher precision of the topography. We therefore conclude that the results of the Aster $30 \mathrm{~m}$ are not adapted for this type of catchment. On the opposite, the DEM derived from Pleiades imagery represents a more suitable model for elevation. The water levels during extreme floods are more accurately reproduced with the Pleaides DEM according to field surveys. This new high-resolution spatial data from Pleiades offers real opportunities for flood risk mapping in such a complex terrain. Due to the recent availability of this high-resolution elevation data, it is possible to implement this type of approach in different catchment to produce accurate flood plains maps.

This study opens different perspectives for future research. First, the hydraulic modelling requires hydro-meteorological data to be implemented, and this type of data is not often available in developing countries. Other approaches relying on lower data requirements and using large scale databases could be implemented to produce maps of flood risk, such as the FIGUSED 
(Kazakis et al. 2015) approach. Second, there is a need to develop a precise spatial knowledge of the local vulnerabilities to floods, the level of danger and the location of the areas most affected by flooding. Coupling the hydraulic modeling with approaches able to quantify the vulnerability of buildings and infrastructures will allow proposing mitigation actions to reduce the impacts of floods.

\section{Acknowledgements}

This study has been conducted in collaboration with the LMI TREMA and LMI MEDITER, the financial support provided is gratefully acknowledged. This work is a contribution to the HYdrological cycle in The Mediterranean EXperiment (HyMeX) program, through INSU/MISTRALS support and the support of the Socially Responsible Projects of Cadi Ayyad University.

\section{References:}

1. Ahattab, J., Serhir, N., and Lakhal, E.K. (2015). Vers l'élaboration d'un système d'aide à la décision pour le choix des méthodes d'estimation des débits max des crues : réadaptation aux données hydrologiques récentes. La Houille Blanche 1, 63-70.

2. Akaike, H. (1974) A new look at the statistical model identification. IEEE Trans. on Automatic Control 19, 716-723.

3. Apel, H., Thieken, A., Merz, B., and Bloschl, G. (2006). A probabilistic modelling system for assessing flood risks. Natural Hazards 38 (1-2): 79-100.

4. Arduino, G., Reggiani, P., and Todini, E. (2005). Recent advances in flood forecasting and flood risk assessment. Hydrology and Earth System Sciences 9 (4): 280-284.

5. Arino O., Bicheron P., Achard F., Latham J., Witt R. and Weber J. L. (2008). Globcover: the most detailed portrait of Earth, ESA Bulletin 136, 24-31.

6. Bagnardi, M., Gonzalez, P.J., and Hooper, A. (2016). High-resolution digital elevation model from tri-stereo Pléiades-1 satellite imagery for lava flow volume estimates at Fogo Volcano. Geophysical Research Letters 43(12): 6267-6275.

7. Borga, M., Anagnostou, E.N., Blöschl, G., and Creutin, J.D. (2010). Flash floods: observations and analysis of hydrometeorological controls. Journal of Hydrology 394(1) : 1-3.

8. Brunner, G.W., (2016). HEC-RES River Analysis System - User's Manual Version 5.0. US Army Corps of Engineers. Institute forWater Resources, Hydrologic Engineering Center (HEC), p. 962. 
9. Chow VT (1959). Open channel hydraulics. McGraw-Hill Book Company, New York.

10. Daoudi L., and Saidi M.E.M. (2008). Floods in semi-arid zone: example of the Ourika (High Atlas of Marrakech, Morocco). International Scientific Journal for Alternative Energy 5(61): 117-123.

11. Dawod G., Al-Ghamdi K.A. (2017). Reliability of Recent Global Digital Elevation Models for Geomatics Applications in Egypt and Saudi Arabia. Journal of Geographic Information System 9(6), 685698. DOI: $10.4236 /$ jgis.2017.96043.

12. Di Baldassarre, G., Montanari, A., Lins, H., Koutsoyiannis, D., Brandimarte, L., and Blöschl, G. (2010a). Flood fatalities in Africa: From diagnosis to mitigation. Geophysical Research Letters 37(22): 26.

13. Di Baldassarre, G., Schumann, G., Bates, P.D., Freer, J.E., and Beven, K.J. (2010b). Flood-plain mapping: a critical discussion of deterministic and probabilistic approaches. Hydrological Sciences Journal 55(3): 364-376.

14. Douglas, I., Kurshid, A., Maghenda, M., McDonnell, Y., McLean, L., Campbell, J. (2008). Unjust waters: climate change, flooding and the urban poor in Africa, Environ. Urban., 20, 187-205.

15. Dutta, D., Herath, S., and Musiake, K. (2006). An application of a flood risk analysis system for impact analysis of a flood control plan in a river basin. Hydrological Processes 20 (6): 1365-1384.

16. El Adlouni, S., Bobée, B., and Ouarda, T.B.M.J. (2008). On the tails of extreme event distributions in hydrology. Journal of Hydrology 355 : 16-33.

17. El Alaoui El Fels, A., and Saidi, M.E. (2014). Simulation et spatialisation du risque d'inondation dans une vallée anthropisée. Le cas de la vallée de l'Ourika (Haut Atlas, Maroc). European Scientific Journal 10(17): 210-223.

18. Forkuor, G., and Maathuis, B. (2012). Comparison of SRTM and ASTER derived digital elevation models over two regions in Ghana Implications for Hydrological and Environmental modeling. Studies on Environmental and Applied Geomorphology (9): 219-240.

19. Fujisada, H., Bailey, G.B., Kelly, G.G., Hara, S., and Abrams, M.J. (2005). ASTER DEM Performance. IEEE transactions on Geoscience and Remote Sensing 43: 2707-2714.

20. Gaume, E., Bain, V., Bernardara, P., Newinger, O., Barbuc, M., Bateman, A., Blaskovicov, L., Blöschl, G., Borga, M., Dumitrescu, A., Daliakopoulos, I., Garcia, J., Irimescu, A., Kohnova, S., Koutroulis, A., Marchi, L., Matreata, S., Medina, V., Preciso, E., Sempere Torres, D., Stancalie, G., Szolgay, J., Tsanis, I., Velasco, D., and Viglione, A. 
(2009). A collation of data on European flash floods. Journal of Hydrology 367: 70-78.

21. Gleyzes, M.A., Perret, L., Kubik, P. (2012). PLEIADES system architecture and main performances. International Archives of the Photogrammetry, Remote Sensing and Spatial Information Sciences 537-542.

22. Horritt, M.S., Bates, P.D. (2002). Evaluation of 1D and 2D numerical models for predicting river flood inundation. Journal of Hydrology 268 (1-4): 87-99.

23. Jung, H.C., Jasinski, M.F. (2015). Sensitivity of a floodplain hydrodynamic model to satellite-based DEM scale and accuracy: case study - The Atchafalaya Basin. Remote sensing 7: 7938-7958.

24. Kääb, A., (2002). Monitoring high-mountain terrain deformation from repeated air - and spaceborne optical data: Examples using digital aerial imagery and Aster data. ISPRS Journal of Photogrammetry and Remote Sensing 57(1-2): 39-52.

25. Karrouchi, M., Touhami, M. O., Oujidi, M., and Chourak, M. (2016). Cartographie des zones à risque d'inondation dans la région TangerTétouan : Cas du bassin versant de Martil (Nord du Maroc). International Journal of Innovation and Applied Studies 14(4): 10191035.

26. Kazakis, N., Kougias, I., and Patsialis, T. (2015). Assessment of flood hazard areas at a regional scale using an index-based approach and Analytical Hierarchy Process: Application in Rhodope-Evros region, Greece. Science of the Total Environment 538: 555-563.

27. Knebl, M.R., Yang, Z.L., Hutchison, K., and Maidment, D.R. (2005). Regional scale flood modeling using NEXRAD rainfall, GIS, and HEC-HMS/ RAS: A case study for the San Antonio River Basin Summer 2002 strom event. Journal of Environmental Management 75(4) : 325-336.

28. Lacroix, P., Berthier, E., and Maquerhua, E.T. (2015). Earthquakedriven acceleration of slow-moving landslides in the Colca valley, Peru, detected from Pléiades images. Remote Sensing of Environment 165: $148-158$.

29. Latron, J., Llorens, P., Gallart, F. (2009). The hydrology of Mediterranean mountain areas. Geography Compass 3(6): 2045-2064.

30. Mallouk, A., Lechgar, H., Malaainine, M.E., and Rhinane, H. (2015). A multicriteria approach with GIS for assessing vunerability to flood risk in urban areas (case of Casablanca city, Morocco). Proceeding of the Mediterranean Conference on Information and Communication Technologies 257-266. 
31. Marti, R., Gascoin, S., Berthier, E., De Pinel, M., Houet, T., and Laffly, D. (2016). Mapping snow depth in open alpine terrain from stereo satellite imagery. Cryosphere 10(4): 1361-1380.

32. Merheb, M., Moussa Roger., Abdallah C., Colin F., Perrin C., Baghdadi N. (2016). Hydrological response characteristics of Mediterranean catchments at different time scales: a meta-analysis. Hydrological Sciences Journal 61(14), 2520-2539.

33. Merz, B., Kreibich, H., Schwarze, R., and Thieken, A. (2010). Review article Assessment of economic flood damage. Natural Hazards and Earth System Sciences 10 (8): 1697-1724.

34. Musa, Z.N., Popescu, I., and Mynett, A. 2015. A review of applications of satellite SAR, optical, altimetry and DEM data for surface water modelling, mapping and parameter estimation. Hydrology and Earth System Sciences 19: 3755-3769.

35. Nardi, F., Vivoni, E.R., and Grimaldi, S. (2006). Investigating a floodplain scaling relation using a hydrogeomorphic delineation method.Water Resources Research 42(9), W09409. http://dx.doi.org/10.1029/2005WR004155.

36. Noman, N.S., Nelson, E.J., and Zundel, A.K. (2001). Review of automated floodplain delineation from digital terrain models. Journal of Water Resources Planning and Management 127 (6): 394-402.

37. Papaioannou, G., Loukas, A., Vasiliades, L., and Aronica, G.T. (2016). Flood inundation mapping sensitivity to reverine spatial resolution and modeling approach. Natural Hazards 83(1): 117-132.

38. Patel, D.P., Ramirez, J.A., Srivastava, P.K., Bray, M., and Han, D. 2017. Assessement of flood inundation mapping of Surat city bu coupled 1D/2D hydrodynamic modeling: a case application of the new HEC-RAS 5. Natural Hazards 89(1): 93-130.

39. Pereira-Cardenal, S.J., Riegels, N.D., Berry, P.A.M., Smith, R.G., Yakovlev, A., Siegfried, T.U., and Bauer-Gottwein, P. (2011). Realtime remote sensing driven river basin modeling using radar altimetry. Hydrology and Earth System Sciences 15: 241-254.

40. Pistocchi, A., and Mazzoli, P. (2002). Use of HEC-RAS and HECHMS models with ArcView for hydrologic risk management. Proceesing IEMSS 305-310.

41. Rao, A.R., and Hamed, K.H. (2001). Flood frequency analysis. CRC Press, New York.

42. Saidi, M.E.M., Daoudi, L., Aresmouk, M., and Blali, A. (2003). Rôle du milieu physique dans l'amplification des crues en milieu montagnard: exemple de la crue du 17 août 1995 dans la vallée de l'Ourika (Haut-Atlas, Maroc. Sécheresse 14(2): 1-8. 
43. Saidi M.E., Daoudi L., Aresmouk M.E., Fniguire F., Boukrim S. (2010). The Ourika floods (High Atlas, Morocco), extreme events in semi-arid mountain context. Comunicações Geológicas, 97, 113-128.

44. Sarhadi, A., Soltani, S., and Modarres, R. (2012). Probabilistic flood inundation mapping of ungauged rivers: Linking GIS techniques and frequency analysis. Journal of Hydrology 458-459: 68-86.

45. Schwartz, G. (1978). Estimating the dimension of a model. The Annals of Statistics 6, 461-464.

46. Shean, D.E., Alexandrov, O., Moratto, Z.M., Smith, B.E., Joughin, I.R., Porter, C., and Morin, P. (2016). An automated, open-source pipeline for mass production of digital elevation models (DEMs) from very-high-resolution commercial stereo satellite imagery. ISPRS Journal of Photogrammetry and Remote Sensing 161: 101-117.

47. Sintondji L. O., Dossou-Yovo E. R., Akogou D., Agbossou E. K. (2017). Flood Hazard Assessment in Agricultural Areas: The Case of the District of Pélébina in the Municipality of Djougou, Bénin. European Scientific Journal. Vol.13, No.32, 235-247. http://dx.doi.org/10.19044/esj.2017.v13n32p235

48. Stedinger, J.R., Vogel, R.M., and Foufoula-Georgiou, E. (1993). Frequency Analysis of Extreme Events. Handbook of Hydrology.

49. Taous, A., Obda, K., Amyay, M., Laaouane, M., Tribak, A., Akdim, B., Marques, M.A., Furdada, G., and Julia, R. (2010). Cartographie et zonage de l'aléa d'inondation à Taza (Maroc). Application de la méthode géomorphologique intégrée. Geomaghreb (6): 1-19.

50. Tate, E.C., Maidment, D.R., Olivera, F., and Anderson, D.J. (2002). Creating a Terrain Model for Floodplain Mapping. Journal of Hydrologic Engineering 7(2): 100-108.

51. Teng, J., Jakeman, A.J., Vaze, J., Croke, B.F.W., Dutta, D., and Kim, S. 2017. Flood inundation modeling: a review of methods, recent advances and uncertainty analysis. Environmental modeling \& software 201-216.

52. Theilen-Willige, B., Charif, A., El Ouahidi, A., Chaibi, M., Ayt Ougougdal, M., and Ait Malek, H. (2015). Flash floods in the Guelmim area/Southwest Morocco - use of Remote Sensing and GISTools for the detection of flooding-prone areas. Geosciences 5: 203221.

53. Timbadiya, P., Patel, P., and Porey, P. (2014). A 1D-2D coupled hydrodynamic model for river flood prediction in a coastal Urban floodplain. Journal of Hydrologic Engineering 20(2). 
54. Tramblay, Y., St-Hilaire, A., and Ouarda, T. (2008). Frequency analysis of maximum annual suspended sediment concentrations in North America. Hydrological Sciences Journal (1): 236-252.

55. Tramblay Y., Bouaicha R., Brocca L., Dorigo W., Bouvier C., Camici S., Servat E. (2012). Estimation of antecedent wetness conditions for flood modelling in Northern Morocco. Hydrology and Earth System Sciences 16, 4375-4386.

56. Vinet F., Saidi M.E., Douvinet J., Fehri N., Nasrallah W., Menad W., Mellas S. (2016). Urbanization and land use as a driver of flood risk. The Mediterranean Region under Climate Change. A Scientific Update. IRD editions, Marseille. 563-575.

57. Werren, G., Reynard, E., Lane, S.N., and Balin, D. (2016). Flood hazard assessment and mapping in semi-arid piedmont areas: a case study in Beni Mellal, Morocco. Natural Hazards 81(1): 481-511.

58. Yamaguchi, Y., Kahle, A., Tsu, H., Kawakami, T., and Pniel, M. (1998). Overview of Advanced Spaceborne Thermal Emission and Reflection Radiometer (ASTER). IEEE Geoscience and Remote Sensing 36: 1062- 1071.

59. Yésou, H., Chastanet, P., Maxant, J., Huber, C., Clandillon, S., Battiston, S., Proy, C., and De Fraipont, P. (2015). Contribution de l'imagerie Pléiades a la cartographie rapide des dégâts suite à des catastrophes majeures: Retour d'expériences après deux ans d'actions de cartographie rapide localisées en Asie, en Afrique, en Europe et aux caraibes. Revue Française de photogrammétrie et de Télédétection 209(209) : 81-88.

60. Zkhiri, W., Tramblay, Y., Hanich, L., and Berjamy, B. (2016). Regional flood frequency analysis in the High Atlas mountainous catchments of Morocco. Natural Hazards 83(2): 953-967. Doi: 10.1007/s11069-016-2723-0

61. Zemzami, M., Benaabidate, L., Layan, B., and Dridri, A. (2013). Design flood estimation in ungauged catchments and statistical characterization using principal components analysis: application of gradex method in upper Moulouya. Hdrological Processes 27(2): 186195.

62. Zoglat, A., El Adlouni, S., Badaoui, F., and Amar, A. (2014). Managing hydrological risks with extreme modeling: application of peaks over threshold model to the Loukkos watershed, Morocco. Journal of Hydrologic Engineering 19(9), doi :10.1061/(ASCE)HE.1943-5584.0000996 